\title{
ANALISIS PENYAJIAN KONSEP DAN SOAL PADA LEMBAR KERJA SISWA (LKS) MATEMATIKA SMK KELAS X TERBITAN CAHAYA MENTARI, SURAKARTA
}

\author{
SUDIYAH ANAWATI \\ sudiahannawati@yahoo.co.id \\ Program Studi Pendidikan Matematika, \\ Fakultas Teknik, Matematika dan Ilmu Pengetahuan Alam \\ Universitas Indraprasta PGRI (UNINDRA) \\ Tanjung Barat, Jagakarsa, Jakarta Selatan
}

\begin{abstract}
This study aimed at analyzing the presentation of concepts and questions on theworksheet vocational high school students firt class a semester publications Cahaya Mentari. Methods of research using qualitative descriptive methods, in this study the authors did not conduct experiments or field research. Method used is literature study method in accordance with references from varioussources related dengnan issues to be addressed. Population taken in this study are the concepts and issues urian short and multiple choice, to serve as study sample. Review the concept based on common benchmark compilation of textbooks, while the review examined a matter of using the rules about the presentation in the form ofdescriptions and multiple choice according to the study of materials, construction andstudy of language.
\end{abstract}

Keywords: Concept,Questions Presentation,Worksheet Students, the literature study

\section{PENDAHULUAN}

Pendidikan nasional yang berdasarkan Pancasila dan Undang-Undang Dasar Negara Republik Indonesia Tahun 1945 berfungsi mengembangkan kemampuan dan membentuk watak serta peradaban bangsa yang bermartabat dalam rangka mencerdaskan kehidupan bangsa. Bertujuan untuk mengembangkan potensi peserta didik agar menjadi manusia yang beriman dan bertakwa kepada Tuhan Yang Maha Esa, berakhlak mulia, sehat, berilmu, kreatif, mandiri, dan menjadi warga negara yang demokratis dan bertanggung jawab.

Peningkatan ikmu pendidikan diarahkan untuk meningkatkan kualitas manusia Indonesia seutuhnya melalui olah hati, olah pikir, olahrasa, dan olahraga agar daya saing dalam menghadapi tantangan global. Berdasarkan tujuan pendidikan dalam Kurikulum Tingkat Satuan Pendidikan (KTSP) yaitu "Tujuan pendidikan menengah kejuruan yang terdiri atas pengetahuan, kepribadian, akhlak mulia, serta keterampilan mandiri dan mengikuti pendidikan lebih lanjut sesuai dengan kejuruannya" (Mulyasa, 2007:179).

Perubahan sistem pendidikan untuk memajukan kehidupan bangsa banyak sekali mengalami kendala apalagi bagi negara yang sedang berkembang seperti Indonesia. Kesenjangan sosial membuat indonesia semakin terpuruk. Dengan proses reformasi pendidikan perubahan dapat terjadi dalam dunia pendidikan.

Perubahan sistem pendidikan dan kukrikulum dari Kulikulum Berbasis Kompetensi (KBK) yang dikenal dengan sebutan Kurikulum 2004 mengakibatkan perubahan paradigma pada proses pembelajaran dan banyak menelurkan pro dan kontra. Namun yang sekarang gencar dibicarakan dalam dunia pendidikan adalah kurikulum satuan pendidikan. Perlu disadari penulis tidak akan menjelaskan apa itu KTSP, karena penulis di sini hanya akan menganalisis konsep-konsep dan soal-soal yang disajikan pada Lembar Kerja Siswa yang penulis teliti. Dalam penilaian KTSP saat ini ada tiga aspek 
penilaian yaitu pemahaman konsep, penalaran dan komunikasi, serta pemecahan masalah. Ketiga aspek tersebut merupakan kajian baru mengingat masih banyak orang yang belum tahu apa itu KTSP.

LKS sebagai media pendidikan dan sebagai sarana pendidikan. Media pendidikan merupakan segala macam bentuk perangsang dan alat yang disediakan guru untuk mendorong siswa untuk belajar, guru sebagai mediator dan fasilitator hendaknya mempunyai pengetahuan dan pemahaman yang cukup tentang media pendidikan karena media pendidikan merupakan alat komunikasi untuk lebih mengefektifkan proses belajar mengajar.

Guru sebagai evaluator yang dimaksud adalah untuk mengetahui apakah tujuan yang telah dirumuskan itu sudah tercapai. Sebagai obyek evaluasi di sini adalah siswa. siswa sebagai obyek penelitian, Apakah standar kompetensi dan kompetensi dasar yang diinginkan sudah tercapai atau belum? Sebelum mengadakan evaluasi hendaknya diberikan pembekalan-pembekalan berupa materi yang dituangkan ke dalan konsepkonsep dan latihan-latihan soal sesuai dengan bidang studi yang diajarkan.

Dalam pembekalan-pembekalan materi dan latihan-latihan soal perlulah LKS dimiliki oleh seorang guru dan siswa sebagai sumber dan bahan belajar yang praktis. Berbagai macam-macam buku pelajaran yang ditawarkan apakah semua sudah memberikan kontribusi yang memuaskan bagi guru maupun siswa sebagai sumber belajar khususnya pelajaran matematika di sekolah mengingat ketiga aspek penilaian yang harus dicapai yaitu aspek pemahaman konsep, penalaran dan komunikasi, serta pemecahan masalah.

LKS merupakan salah satu sumber belajar bagi siswa dan bahan ajar bagi guru bidang studi yang dipelajari. Agar kegiatan belajar mengajar menjadi lebih efektif dan efisien. Dengan demikian, sebelum menggunakan LKS dalam kegiatan pembejaran di kelas. Sebaiknya guru perlu menelaah terlebih dahulu buku yang akan digunakan, kemudian buku dipilih sebagai pegangan popelengkap untuk guru dan siswa. karena pentingnya media pembelajaran dalam kegiatan belajar mengajar di kelas, maka dari itu penukis tertarik dalam kajian masalah tersebut. Penulis ingin menganalisis penyajian Konsep dan Soal pada lebar kerja siswa (LKS) matematika SMK kelas x terbitan Mahaya Mentari Surakarta.

\section{TINJAUAN PUSTAKA \\ Pembelajaran Matematika}

Belajar dan pembelajaran merupakan tindakan dan perilaku siswa yang kompleks. Proses belajar terjadi berkat siswa memperoleh sesuatu yang ada di lingkungan sekitar. Tindakan belajar tentang suatu hal tersebut tampak sebagai perilaku belajar yang tampak dari luar.

Belajar menurut Skiner " Belajar adalah suatu perilaku pada saat orang belajar responnya menjadi lebih baik, sebaiknya bila ia tidak belajar maka responya akan menurun". Ketika seseorang sering belajar maka responnya akan semakin baik, sebaliknya ketika seseorang tidak pernah belajar maka responnya lambat.

Belajar menurut pandangan Piaget " Pengetahuan dibangun dalam pikiran" setiap individu membangun pemikirannya sendiri . pengetahuan yang dibangun terdiri dari tiga bentuk yaitu ; pengetahuan fisik, pengetahuan logika, dan pengetahuan sosial. Belajar pengetahuan meliputi tiga fase yaitu : fase eksplorasi dalam fase ini siswa mempelajari gejala dengan bimbingan, fase pengetahuan konsep siswa mengenal konsep yang ada hubungannya dengan gejala, dan fase aplikasi konsep pada fase ini siswa menggunakan konsep untuk meneliti gejala lain lebih lanjut. 
Menurut Piaget pembelajaran terdiri dari 4 langkah antara lain: langkah pertama nenemukan topik, langkah kedua memilih dan mengembangkan aktifitas kelas dengan topik tersebut. Langkah ketiga, megetahui adanya kesempatan bagi guru untuk memgemukakan pertanyaan yang menunjang proses pemecahan masalah.

Langkah keempat, menilai pelaksanaan tiap kegiatan, dengan memperhatikan keberhasilan dan melakukan revisi.

Oemar Malik dalam bukunya mengatakan: tugas guru adalah berinteraksi dengan sisiwanya dengan cara menciptakan kondisi dan bahan dengan memanipulasi situasi yang memungkinkan siswa mengubah tingkah laku sesuai dengan keinginan sebagaimana mestinya yang telah diramalkan sebelumnya (Oemar Malik,2002:8)

Matematika secara harfiah yang terdapat dalam Kamus Besar Bahasa Indonesia (1989:556) mengartikan bahwa " Matematika adalah ilmu tentang bilangan-bilang dan prosedur operasional dan operasional digunakan dalam pemecahan masalah bilangan". Matematika bersifat abstrak, mengabstrak diartikan sebagai mengambil sifat-sifat karakteristik atau atribut dari apa yang kita lihat atau alami dan mengenal secara terpisah obyek-obyek yang dimiliki.

Menurut Robert Gangne : obyek langsung dapat dibagi menjadi empat kategori yang penting (Ruseffendi 1991 : 187). a) Fakta adalah konvensi-konvensi yang diungkap dengan simbol-simbol tertentu, b) Konsep adalah ide abstrak yang dapat digunakan untuk menggolongkan atau mengklasifikasikan sekumpulan obyek, apakah obyek tertentu merupakan konsep atau bukan, c) Operasi dan relasi adalah pengerjaan hitung, pengerjaan aljabar dan pengerjaan matematika lain dengan aturan untuk memperoleh elemen tunggal dari satu atau lebih elemen yang diketahui, d) aturan dan prinsip adalah hubungan antara beberapa obyek dasar matematika berupa aksioma, teorema, sifat dan dalil.

Pembelajaran adalah aktifitas dimana guru dan siswa saling berinteraksi pada proses belajar mengajar, sehingga terjadi komunikasi dua arah antara guru dengan siswa.

Matematika adalah ilmu yang mempelajari tentang cara penalaran logis yang memiliki nilai praktis, disiplin dengan obyek abstrak yang berupa ide?konsep abstrak yang tersusun secara sistematis yang diwujudkan dalam simbol-simbol serta penalaran bersifat dedukkutif.

Berdasarkan pemaparan di atas, maka dapat disimpulkan bahwa pembelajaran matematika adalah aktifitas dimana guru dan siswa saling berinteraksi pada proses belajar mengajar, sehingga terjadi komunikasi dua arah antara guru dengan siswa dalam mempelajari cara penalaran logis yang memiliki nilai praktis, disiplin melalui obyek abstrak yang tersusun secara sistematis yang diwujudkan dalam simbol-simbol serta penalaran bersifat deduktif.

\section{Lembar Kerja Siswa (LKS)}

Lembar Kerja Siswa (LKS) menurut Kamus Besar Bahasa Indonesia adalah bagian pokok dari modul yang berisi topik yang dibahas, diuji bagian modul berisi soal yang harus dijawab oleh para siswa setelah mereka menyelesaikan lembar kegiatan siswa(1996:656). Lembar Kerja Siswa merupakan teks pelengkap yang digunakan dalam kegiatan belajar dan pembelajaran. LKS dapat dijadikan buku pokok karena didalamnya terdapat kumpulan materi-materi pembelajaran dan soal-soal latihan matematika untuk satu semester. LKS selalu hadir dan perubahannya disesuaikan dengan kompetensi dan kompetensi dasar dalam standar isi yang ditetapkan dalam peraturan mendiknas Nomor 22 Tahun 2006. (2007:1)

Berdasarkan uraian di atas dapat disimpulkan bahwa LKS adalah bagian pokok dari modul yang berisi topik yang dibahas, serta soal-soal/latihan-latihan yang diharus di jawab oleh siswa sebagai sarana pembelajaran. 


\section{Kaidah Penyusunan Teks}

Penyusunan teks berdasarkan patokan umum yang berlaku meliputi : 1) Pendekatan, menggunakan pendekatan keterampilan proses yang mencakup keterampilan mengenal, mengingat, menjumlahkan, mengurang, membagi dan mengali serta menerapkan. 2) Tujuan, menumbuhkan dan mengembangkan keterampilan berhitung sebagai bekal kemampuan dasar matematika. 3) Bahan Pengajaran, disajikan secara bertahap dari konsep sederhana ke konsep yang lebih sulit. 4) Program, program pengajaran menggunakan sistem semester satuan pendidikan. 5) Metode, menggunakan metode yang banyak melibatkan siswa dalam belajar baik secara fisik. Mental maupun soaial. 6) Sarana dan Sumber, menggunakan sarana dan sumbe $r$ belajar sederhana yang ada dalam lingkungan sekolah. 7) Penilaian, menggunakan tes obyektif maupun uraian. 8) Bahasa, menggunakan bahasa yang sederhana serta mudah dimengerti.

\section{Kaidah Penyajian Soal}

1. Materi, a) soal harus sesuai dengan indikator, artinya soal harus menanyakan materi yang hendak diukur dengan ketentuan indikator.b) ditinjau dari segi materi pilihan jawaban harus homongen dan logis artinya semua pilihan jawaban harus berasal dari materi yang sama seperti yang ditanyakan pokok soal, penulisannya harus setara dan semua pilihan jawaban harus berfungsi.

2. Konstruksi, a)pokok soal harus dirumuskan secara singkat, padat dan jelas. b) rumusan soal dan pilihan jawaban harus merupakan pernyataan yang perlu saja. c) pokok soal tidak memberi petunjuk ke arah jawaban yang benar. d) panjang rumus pilihan jawaban harus relatif sama. e) pilihan bentuk angka harus disusun berdasarkan besar dan kecilnya angka. f) gambar garafik, tabel, diagram dan sejenisnya yang terdapat pada soal haruss jelas dan berfungsi. g) butir soal jangan tergantung pada jawaban soal sebelumnya.

3. Bahasa, a) setiap soal harus menggunakan bahasa yang sesuai dengan kaidah bahasa indonesia, b) jangan menggunakan bahasa yang berlaku setempat, bahasa harus bersifa umum dan nasional. c) pilihan jawaban jangan mengulang kata atau frase yang bukan merupakan satu kesatuan pengertian.

\section{Kaidah Penyusunan Soal}

1. Bentuk uraian, bentuk uraian dalan literatur lain disebut juga essay examination, merupaka alat penilaian hasik belajar yang paling tua. Secara umum tes uraian ini adalah pertanyaan yang menuntut siswa menjawabnya dalam bentuk menguraikan, menjelaskan, membandingkan, memberikan alasan dan bentuk lainnya yang sejenis dengan tuntutan pertanyaan dengan menggunakan kata-kata bahasa sendiri.

2. Bentuk Pilihan Ganda, soal dalam bentuk pilihan ganda adalah bentuk soal yang jawabannya darus dipilih dari beberapa kemungkinan jawaban yang telah disediakan. Secara umum setiap butir soal pilihan ganda terdiri dari pokok soal pilihan ganda (item) dan pilihan jawaban (optian). Kunci jawaban adalah jawabany yang paling benar. Pengecoh merupakan jawaban yang tidak benar namun seseorang akan memilihnya apabila tidak menguasai materi pelajaran.

\section{Penelaahan Soal}

Penelaahan soal ditelaan dengan kriteria : a)Telaah Materi, soal ditelaah untuk mengetahui kesesuaian isi atau materi yang ditanyakan dengan tujuan pertanyaan yang tersirat dalam indikator. b) Telaah Konstruksi, Soal yang baik harus mengikuti kaidah penulisan soal. c) Telaah Bahasa, untuk melihat bahasa suatu soal sudah jelas dan 
komunikatif, sehingga mudah dimengerti oleh siswa dan tidak menimbulkan pengertian dan penafsiran ganda.

\section{Kurikulum Matematika SMK}

Pendidikan kejuruan bertujuan untuk meningkatkan kecerdasan, pengetahuan, kepribadian akhlak mulia, serta keterampilan peserta didik untuk hidup mandiri dan mengikuti pendidikan lebih lanjut sesuai dengan program kejuruannya. Agar dapat bekerja secara efektif dan efesien serta mengembangkan keahlian dan keterampilan, mereka harus memiliki stamina yang tinggi, mengusai bidang keilmuan dan dasar-dasar ilmu pengetahuan dan teknologi, memiliki etos kerja yang tinggi, dan mampu berkomunikasi sesuai dengan tuntutan pekerjaannya serta memiliki kemampuan mengembangkan diri.

Sesuai dengan Peraturan Menteri Pendidikan Naional republik Indonesia nomor 22 tahun 2006 tentang Standar Isi untuk satuan Pendidikan dasar dan Menengah.

"Standar isi satuan Pendidikan Dasar dan Menengah yang selanjutnya disebut Standar isi mencakup lingkungan materi minimal dan tingkat kompetensi minimal untuk mencapai kompetensi lulusan minnimal pada jenjang dan jenis pendidikan tertentu".

Dalam struktur kurikulum SMK/MAK mata pelajaran matematika disesuaikan dengan program kejuruan antara lain sebagai berikut :

1. Matematika kelompok seni, Pariwisata, dan Teknologi kerumahtanggaan

2. Matematika kelompok sosial, Administrsi Perkantoran dan akutansi

3. Matematika kelompok Teknologi, Kesehatan dan Pertanian

Untuk Standar Kompetensi Lulusan (SKL) mata pelajaran matematika SMK dapat dilihat pada peraturan Menteri Pendidikan Nasional Republik Indonesia Nomor 23 tahun 2006 tentang Standar Kompetensi Lulusan.

\section{METODE}

\section{Tujuan penelitian}

Peneelitian ini bertujuan untuk:

1. Menganalisis penyajian materi yng disertai pembahasan konsep yang tepat.

2. Untuk mengetahui kualitas penyajian soal dalam bentuk uraian singkat dan pilihan ganda pada LKS ditinjau dari segi kaidah-kaidah penyajian soal

3. Untuk mengetahui relevansi soal dalam bentuk uraian singkat dan pilihan ganda pada LKS sesuai dengan silabus Matematika SMK.

\section{Waktu penelitian}

Pelaksanaan penelitian dilakukan selama enam bulan dari bulan April sampai september 2007.

\section{Metode Penelitian}

Metode yang digunakan dalam penelitian ini adalah deskriptif kualitatif, sehingga dalam penelitian ini penulis tidak melakukan penelitian lapangan ataupun eksperimen. Metode yang digunakan penulis adalah metode studi literatur atau stadi kepustakaan sesuai referensi dari berbagai sumber.

\section{Subyek Penelitian}

Populasi yang diambil dalam penelitian ini adalah konsep-konsep dan soal-soal urian singkat dan pilihan ganda, untuk dijadikan sampel penelitian. 


\section{HASIL dan PEMBAHASAN Deskripsi Penelitian}

Pada dasarnya obyek penelitian pada buku ini dilakukan dengan "membedah" LKS untuk SMK Kelas X semester 1 terbitan Cahaya Mentari tahun 2006. Membedah LKS dalam artian mengkaji substansi LKS tersebut berdasarkan pada dasar-dasar penyusunan LKS. Termasuk didalamnya melakukan evaluasi, kritik, dan memberikan masukan jika ada kekurangan dalam konsep, baik tulisan maupu soal-soal serta mengkaji soal-soal bentuk uraian dan pilihan ganda.

\section{Analisis Relevansi Penyajian Konsep}

Penyajian konsep dan materi LKS SMK kelas X semester 1 terbitan cahaya mentari ternyata terdapat 3 dari 21 materi belum seluruhnya relevan dan masih harus direvisi. Diantaranya pada bab operasi Bilangan real tentang akar pangkat, akar dan logaritma. Selain itu tidak perlu direvisi.

\section{Analisis Penyajian Soal}

Hasil penelaahan LKS tersebut dianalisis berdasarkan tiga hal yaitu:

Telaah materi, semua soal sudah sesuai dengan materi yang ditanyakan dengan tujuan yang tersirat dalam indikator pada silabus SMK mata pelajaran matematika.

Telaah Konstruksi, penyajian soal dalam LKS belum memenuhi kaidah penulisan soal. hal ini dapat dilihat dari kaidah-kaidah penulisan soal pada telaah konstruksi point 4 yaitu pilihan jawaban yang berbentuk angka atau waktu harus disusun berdasarkan besar kecilnya angka, karena 70 soal padah soal pilihan ganda pilihan jawaban tidak disususn berturutan berdasarkan besar kecilnya angka.

Telaah Bahasa, bahasa pada setiap item soal sudah cukup jelas dan komunikatif, sehingga mudah dimengerti siswa dan tidak menimbulkan pengertian dan penafsiran ganda ataupun penafsiran yang berbeda.

\section{Kesesuaian Soal dengan Silabus}

Analisis penyajian soal berdasarkan kesesuaian soal dengan silabus. Ternyata ada 6 indikator yang tidak terwakili dan 21 indikator terwakili dalam soal-soal baik dalam bentuk pilihan ganda maupun uraian.

\section{PENUTUP}

Dari hasil penelitian diatas dapat disimpulkan bahwa Lks dapat dijadikan pengangan bagi guru maupun siswa, namun harus ditelaah terlebih dahulu oleh guru. Penelaahan konsep dilakukan dengan merelevansikan konsep yang ada di LKS dengan penyajian konsep pada buku-buku lain, sehingga menambah wawasan guru dan menambah pemahaman bagi siswa yang aktif membaca. Dalam penelaahan penyajian soal dilakukan melalui tiga hal yaitu telaah materi, konstruksi dan bahasa. Setiap penalaahan konsep maupun soal berdasarkan silabus yang terdapat dalam standar isi dan standar kempetensi kelulusan sekolah menengah.

\section{DAFTAR PUSTAKA}

Badudu, J.S dan Sutan Muhammad Zain. 1996. Kamus Umum Besar Bahasa Indonesia. Jakarta: Pustaka Sinar Harapan.

Fathoni, Abdurrahmat. 2006. Metodologi Penelitian dan Teknik Penyusunan Skripsi. Jakarta: Rineka Cipta.

Hamalik, Oemar. 2001. Kurikulum dan Pembelajaran. Jakarta: Bumi Aksara. 2004. Proses Belajar dan Pembelajaran. Jakarta: PT. Bumi Aksara. 
Kurnianingsih, Sri dkk. 2004. Matematika SMA. Jakarta: Erlangga.

Mulyasa. 2007. Kurikulum Tingkat Satuan Pendidikan. Bandung: PT. Remaja Rosda Karya.

Negoro, ST. dan Harahap B. 2005. Ensiklopedi Matematika. Bandung: Ghalia Indonesia

Ruseffendi, E.T. 1989. Dasar-dasar Matematika Modern dan Komputer untuk Guru. Bandung: Tarsito

Seputro, T dan Theresia M.H. 1992. Pengantar Dasar Matematika. Jakarta: Erlangga.

Subino, H., dkk. _... Teknik-teknik Evaluasi Konstruksi dan Analisa Item. Bandung: FIP IKIP Bandung

Sudjana, Nana. 1982. Evaluasi Hasil Belajar dan Analisa. Bandung: Martina.

Sujono. 1988. Pendidikan Matematika untuk Sekolah Menengah. Jakarta: Depdikbud.

Tarigan, Heri Guntur dan Djono Tarigan. 1986. Telaah Buku Teks Bahasa Indonesia. Bandung: Angkasa

Utari G,. Tono Sutarto dan Cartono. 2006. Penilaian Berbasis Standar. Bandung: Prima Press.

Wayan, Nirakancana dan Sumartana PPN. 1983. Evaluasi Pendidikan. Surabaya: Usaha Nasional.

www.duniaguru.com/indeks.php,2008, Standar Isi Untuk Satuan Pendidikan dan Menengah, Jakarta.

www.duniaguru.com/indeks.php,2008, Standar Kompetensi Lulusan Untuk Satuan Pendidikan dan Menengah, Jakarta. 